\title{
Gas on the Fire: Great Power Alliances and Petrostate Aggression
}

\author{
Inwook Kim and Jackson Woods \\ The George Washington University
}

\begin{abstract}
What causes petro-aggression? Conventional wisdom maintains that the regime type of petrostates has significant effects on a likelihood of petrostates launching revisionist MIDs While domestic politics is an important factor that explains the motivation and behavioral patterns of a petrostate, it says little about the international environment under which a petrostate decides to initiate conflicts. Petro-aggression does not take place devoid of concerns for the possible international backlash that its aggression could inflict on itself. One significant factor that presents opportunities and constraints for petro-aggression is a great power alliance. In essence, the great power has strong incentives not to upset the relationship with its client petrostate ally for both strategic and economic reasons, and hence tends not to oppose military adventurism by its ally. Consequently, the petrostate's anticipation of great power inaction or even protection for its revisionist policy creates a moral hazard problem. Overall, by offering favorable circumstances, a great power alliance has a positive effect on petro-aggression. Although not without caveats, our large- $n$ model and case study bear out this conclusion.
\end{abstract}

\section{Acknowledgement}

The authors thank Brandon Bartels, Jeff Colgan, Charles Glaser, Seok-Joon Kim, and Eric Lawrence for their thoughtful comments. Earlier drafts were presented at the 2013 Annual Conference of the Midwest Political Science Association, Virtual Conference on Resource Politics in 2013, and the 2014 Annual Conference of the International Studies Association.

Word Count: 10,115 


\section{Introduction 1}

Defying the popular depiction of petrostates ${ }^{2}$ as victims of international competition for resources (Homer-Dixon 1999; Klare 2001), recent work has uncovered a strong correlation between oil-abundance, regime type, and propensity to launch MIDs (Colgan, 2010). What makes petrostates potentially aggressive actors in the international system? Is oil 'devil's excrement' for international peace, or are its effects more contingent?

We argue that the presence of a great power alliance significantly increases petrostates' proneness to conflicts for two reasons. First, the strategic and commercial values unique to oil induce great powers to avoid upsetting their relationships with petrostates. Second, a great power alliance provides petrostates with further incentives to behave aggressively through deterrence, entrapment, and enhanced interest effects. Overall, petrostates allied with great powers anticipate that their great power allies will acquiesce to, or even support, their revisionist policies, as long as the core interests of the great power are not threatened. The combination of oil and alliance creates a particularly strong moral hazard problem for petrostates allied with great powers when pursuing disputes with neighbors.

Our argument shares the widely-held view that oil's effects are generally conditional, not absolute (Ross 2014). We acknowledge and build on the argument that petro-aggression is contingent upon the presence of revolutionary government (Colgan 2010, 2013a). Petro-

\footnotetext{
${ }^{1}$ Data for the replication of results presented in this paper, along with explanatory materials, may be obtained at https://dataverse.harvard.edu/dataset.xhtml?persistentId=doi\%3A10.7910\%2FDVN\%2FDBWPVK 2 Petrostates are defined as a state whose oil export constitutes more than $10 \%$ of its GDP. See Colgan (2010).
} 
aggression, however, is a complex phenomenon that cannot be explained by a single condition, and the posited revolutionary variable should be regarded as a useful starting point rather than the final say in comprehending how and why petrostates initiate conflicts. Our paper expands this discussion by shifting the analysis to the international context under which petrostates launch MIDs.

Petro-aggression has historically affected international security in consequential ways, most demonstratively in the Middle East, and oil continues to be at the center of contemporary militarized disputes between states in Africa and Central Asia. By highlighting international causes for petro-aggression, our analysis suggests several policy principles for great powers to moderate their petrostates allies' impulse for revisionist policies. Primarily, their policies should focus on lessening the moral hazard problem that a mixture oil and great power alliance generates exceptionally strongly. We suggest that great powers may be well-advised to make public and explicit that their commitments to oil-state allies are limited to conflicts of a defensive nature, exercise their leverages in bilateral arms trade or multilateral security bodies, and make the costs impending aggression specific and larger.

This paper is structured as follows. The next section critically reviews the literature on petro-aggression. The following section outlines the theoretical framework, illustrating how a blend of oil-abundance and great power alliance foments petro-aggression. The next two sections test our theory using a large-n evaluation and a case study that generally 
bears out our argument. Our case is Iran's occupation of the Abu Musa and Tunbs islands in 1971. Absent revolutionary government, Iran's revisionist policy was strongly facilitated by a favorable regional environment created by the combination of its oil wealth and alliance with the US. The last section concludes, discussing policy implications of our finding.

\section{Bringing in the International Factors}

Oil was long regarded as "the prize" (Yergin 1992) to capture, causing a quest for oil to frequently take violent forms. Although a link between oil and interstate conflicts is intuitive, only recently did scholars begin to produce systematic studies examining the role of oil in interstate conflicts (Acemoglu et al. 2011; Klare 2001; Glaser 2013; Colgan 2013b; Hughes and Long,2014/15). Conventional wisdom according to the so-called resource war literature maintains that petrostates are victims of international competition for oil, who suffer from an unfortunate fate imposed by their comparative advantage: oil-abundance.

However, statistical evidence lends little support to this victimization narrative (De Soysa et al 2009; Colgan 2010, 2013a). Instead, petrostates engage in 94\% more MIDs as aggressors than non-petrostates (Colgan 2010) thereby making such petro-aggression the most significant relationship between oil and international security. 
Oil's effects on a petrostate's aggressive impulse are diverse, however. On one hand, oil increases the petrostate's proneness to conflict by insulating the leader from domestic opposition and increasing military capabilities with its oil income. At the same time, however, oil generates strong incentives to respect the status quo international system that makes the complex and lucrative oil trade possible.

What determines which incentives dominate? Colgan maintains that the nature of domestic politics determines whether leaders of oil exporting nations have aggressive, riskacceptant preferences, and that petrostates led by 'revolutionary' leaders are dramatically more aggressive and launch MIDs at more than three times the rate of comparable nonpetrostates (Colgan 2010, 2013). Two characteristics associated with revolutionary government account for this higher propensity to initiate a conflict. First, habits and skills of solving political conflict by force are more prevalent among revolutionary leaders. Second, revolutionary governments are more likely to enjoy the removal of domestic constraints on the executive. Overall, the combination of oil and revolutionary government is a "toxic mix for international peace and security".

We contend that this revision to the existing debate remains incomplete. Most problematically, the international environment stays constant and exogenous in the domestic-oriented analysis. In reality, petrostates operate under varying sets of international opportunities and constraints, which in turn deeply intervene in petrostates' calculus for launching MIDs. Therefore, while a mix of oil and revolutionary history may make petrostates particularly reckless and violent, the surrounding international context 
can suppress or amplify the recklessness. For instance, few doubted Saddam Hussein's sharp belligerence, but Saddam's recklessness also had been moderated on several occasions by the broader strategic environment, which he perceived as capable of inflicting larger costs on his regime. ${ }^{3}$

International contexts of petrostates' foreign relations significantly shape at least three dimensions relevant to petro-aggression. First, the international context informs a petrostate's assessment about the severity of potential military repercussions from its aggression. More specifically, military repercussions correspond to the willingness and capability of the target, its allies, or other states to punish the planned petro-aggression. Repercussions can take a variety of forms such as escalation of tension, reputational costs, retaliatory attacks and others. Severe military repercussions are anticipated to reduce the incentives for petro-aggression, while anticipation of inaction or an inconsequential military backlash will create added incentives for aggression. For instance, Saddam Hussein's decision to invade Kuwait in 1990 was partly driven by a misperceived green light from the US as succinctly stated in Ambassador Glaspie's famous quote: "We have no opinion on the Arab-Arab conflicts, like your border disagreement with Kuwait." (New York Times, 1990) ${ }^{4}$ Scholars believe that a firm and explicit threat of punishment could have prevented Saddam from launching his offensive (Mearsheimer and Walt 2003). For any rational leaders who are concerned with regime survival and stability, military backlash is a key factor to consider before launching a militarized dispute.

\footnotetext{
${ }^{3}$ See Byman et al (1998) for more detailed description of such cases such as the 1975 Algier Agreement and backing down from a second invasion of Kuwait in 1994.

${ }^{4}$ http://www.nytimes.com/1990/09/23/world/confrontation-in-the-gulf-us-gave-iraq-little-reason-not-tomount-kuwait-assault.html
} 
Second, a petrostate's foreign relations can amplify or mitigate the possible economic backlash from its aggressive behavior. Initiating international conflict in pursuit of revisionist policies can incur substantial financial opportunity costs in the short-run, risk overseas assets, and harm the long-run global reliance on oil (Colgan 2010). Problematically, these costs are assumed to apply equally to all petrostates. This does not necessarily hold in reality, especially regarding short-run costs and overseas assets. Rather, the likelihood or severity of repercussions is a function of the relationship with trade partners and host states of the foreign assets. US-friendly oil states such as Saudi Arabia, pre-1979 Iran, or Nigeria hardly faced economic backlash from the pursuit of limited revisionist policies in their respective regions. Rather, what inflicted economic and financial costs were mostly the aggressions by more hostile petrostates such as post-1979 Iran or Saddam's Iraq.

Third, the international context can affect a petrostate's military power itself. Domesticlevel analysis cannot capture oil's differentiating impact on making a petrostate "more capable of engaging in militarized disputes should it choose to do so" (Colgan, 2010: 669), overlooking the unequal distribution of arms-purchasing power and access to cutting-edge weapon systems across petrostates. In particular, the international environment is directly relevant to the latter. The most advanced weapons systems are produced only in selective advanced industrialized countries, and decisions to sell them abroad are usually based on a combination of commercial incentives, politics, and strategic calculations. Petrostates with 
preferential access to advanced weapon systems, other things being equal, are likely to possess greater military capability..

The variations in military repercussions, economic backlashes, and military power are primarily caused by the petrostate's foreign relations under a specific international setting. These international dimensions, in turn, should alter the likelihood of petro-aggression in significant ways, in addition to the consequences of revolutionary government. And yet, the interaction between the international environment and petrostate behavior remains to be theorized and systematically tested with available data. ${ }^{5}$

\section{“Gas on the Fire:" Why Petrostates with Great Power Allies are More}

\section{Revisionist}

International politics and the relationships between states may impact MID initiation by petrostates in a number of theoretically distinct ways. We focus here on alliances with great powers, the states that clearly occupy the first rank in total military and economic power in the international system at any given time. ${ }^{6}$

Our theory suggests that oil states enjoy certain advantages which, in combination with great power alliances, give them greater latitude for aggression than other states. In the simplest terms, these factors create a serious moral hazard problem which emboldens a

\footnotetext{
${ }^{5}$ De Soysa et al (2009) are an exception, which argue that great powers are likely to tolerate petrostates' pursuit of revisionist foreign policy as the cost of constraining petrostates can be considerable. This analysis suffers from two weaknesses. First, de Soysa et al do not specify what these 'costs' of restraining petrostates are. Second, they implicitly assume that great powers provide an equal safety net to all petrostates. ${ }^{6}$ This definition of "great power" is functionally similar to the concept of polarity. See Waltz (1979), Mearsheimer (2001), Glaser (2010).
} 
petrostate "to behave aggressively because it is insulated from the risks of its own actions." (Benson 2012) Petrostates are less likely to face intra-alliance consequences for their actions, and may even pass part of the burden to their patrons. ${ }^{7}$

The following section elaborates this theory. First, we offer two characteristics of oil wealth that enhance petrostates' importance to great powers: importers' requirement for a stable oil market and strategic competition for access to friendly oil among great powers. Second, we provide three alliance factors explaining why oil states allied with great powers will enjoy further incentives to behave aggressively. In sum, those oil states allied with great powers will tend to make more threats because they are freer to do so.

\section{From Oil to Aggression}

Oil has been long regarded as a strategic commodity: it is indispensable in running an industrialized economy and modern military, and has few substitutes in the short run. The uniqueness of oil as a resource naturally has created strategic interests among great powers, which in turn responded with varying levels of military readiness (Rovner and Talmadge, 2014). Their crucial dependence on oil recently drew scholars to the oil-induced moral hazard problem (de Soysa et al 2009), but the cause of great powers' inability to restrain petrostates' revisionist policies remains unspecified. Rather, the strategic value of oil is simply assumed and asserted. This section fills this gap by laying out two primary concerns that underpin great powers' interests in petrostates.

\footnotetext{
${ }^{7}$ Moral hazard problem within alliances have been constantly visited by security alliance scholars. See Snyder, 1984; Yuen, 2009; Benson, 2012.
} 
First, great powers need to ensure a stable supply of oil at a reasonable price. For an oildependent great power, maintaining a friendly oil-export policy is vital for its domestic and international interests. Disruption in the oil supply or even unanticipated price increases can have immediate and damaging effects on advanced industrialized economies, as the oil crises of the 1970 s spectacularly demonstrated. ${ }^{8}$ Even more serious are the potential effects on modern militaries, since "armies, navies, and air forces that do not have enough oil simply cannot function effectively if pitted against an adversary with plenty of it." ${ }^{9}$ (Kelanic 2012) In addition, even great powers with relatively high domestic oil production will still have a strong interest in ensuring a stable oil market as long as they have a stake in global economic stability or important allies who are themselves import-dependent. An autarkic great power might be imagined, but a great power with little interest in stable and affordable world oil supplies seems unlikely in practice.

Naturally, petrostates also suffer major distress from oil disruptions, as their economies predominantly rely on secure energy exports. In fact, exporters benefit economically from supply reductions only under stringent conditions: when reductions are followed by a more than proportionate price increase and sustained by effective coordination among participating oil-exporters. ${ }^{10}$ These are not easily attainable conditions for most oil-

\footnotetext{
${ }^{8}$ From 1973 to 1975 , for instance, GDP fell by 6\% and unemployment doubled to $9 \%$ in the US as a result of OPEC's oil embargo. The adverse ramifications of the embargo extended to US grand strategy when oildependent allies such as the European Community and Japan deviated from US policy and publicly endorsed the Arab position in November 1973. See Hamilton (1983).

${ }^{9} \mathrm{~A}$ historical example would be the severe military disadvantages that oil-deficient Germany and Japan faced during the Second World War against the oil-abundant US and its allies. See Yergin (1992)

${ }^{10}$ Effective coordination among oil producers is notoriously difficult because of incentives to cheat and lack of monitoring and punishment mechanisms. Moreover, Saudi Arabia has typically been willing and able to
} 
exporters, and historically exporters have been cautious not to upset the world's long-run dependence on oil by creating short-run shocks.

However, despite exporters' caution about utilizing oil coercively, the risk-averse importer's anxiety about a possible oil crisis remains quite another matter. Although the chance of an oil shock at any given moment may be low, oil-importers have strong incentives to forestall the possibility of an oil crisis as comprehensively as possible. ${ }^{11}$ In practice, these incentives may discourage oil-dependent great powers from intervening in petrostates' foreign policies, as long as they do not pose threats to securing a reliable oil supply at a reasonable price or other important foreign policy objectives. ${ }^{12}$

Second, great powers seek not only to secure a safe oil supply but also to deny their adversaries access to oil. Oil's non-renewability and irreplaceability makes the inter-state competition for oil exhibit zero-sum game dynamics, especially in the short and medium run. Unlike other traded commodities, therefore, loss of imported oil to rival states can inflict significant financial costs through price hikes or military disadvantages when supplies are cut, neither of which can be easily overcome in the near term.

maintain oil prices during temporary disruptions by utilizing its own spare capacity, which serves long-run Saudi interests.

${ }^{11}$ Note that most security scholars view states' concern over future oil crises as essentially unwarranted (Gholz and Press, 2010)For the purposes of our argument, however, it matters only that importers worry about the possibility of such a crisis, not whether they are ultimately correct or mistaken in doing so.

12 Iraq's invasion of Kuwait in 1990 is exactly the type of petrostate aggression that great powers would never tolerate, as the successful annexation of Kuwait would give Iraq roughly equal market power as Saudi Arabia in the oil trade. 
The strategic pressure to deny an adversary's access to oil has two implications for great power-petrostate relations. To begin with, even great powers with sufficient oil reserves have a vested interest in keeping petrostates close in order to deny potential adversaries' access to oil. The value of denial varies with the adversary's oil dependence, since a comprehensive denial of the adversary's access to oil is highly effective in hampering its capability to carry out military operations. The most successful example of such a denial strategy is found in the Allied forces' operations against oil-dependent Germany and Japan during the Second World War (Yergin 1992, Kelanic 2012). The Soviet Union's interest in the Middle East during the early Cold War also partly rested upon the West's reliance on the region's oil, since Soviet oil resources were already adequate domestically (Ross 1981). Overall, the strategic value of having petrostates as allies, or at least keeping them out of the adversary's camp, extends even to those great powers with sufficient internal reserves.

The second implication of denial's value is the ability of petrostates to exploit the strategic rivalry between great powers. As part of a denial strategy, great powers have an incentive to prevent a friendly petrostate's defection to its adversary, as well as to encourage the defection of its adversary's petrostate allies. For petrostates, these great power rivalries offer the chance to extract additional policy autonomy or other benefits. For instance, when the Kennedy administration showed reluctance to issue a second credit package to Iran at a reduced interest rate, the Shah approached the Soviet Union and signed a trade credit agreement in 1965, sparking a series of credit agreements with the 
USSR and the East European bloc (al-Saud 2003: 24-25). ${ }^{13}$ The Shah's brief rapprochement with the USSR paid off when the US responded with a second 50 million dollar slice of credit at a reduced 5\% interest rate in 1967. Overall, the rationale for Soviet and American competitive loan offers to Iran in this period reflected attempts to undermine one another's influence. This is exactly the type of exploitation of great power divisions that we would expect.

\section{Alliance Dynamics}

The two above characteristics of oil wealth - its strategic necessity and conversely the value of denial - provide reason for us to believe that petrostates have greater freedom of movement in the international system. Two questions remain, however. First, why should alliances matter? Even unallied oil states can benefit from great powers' interest in maintaining oil flows and exploit the divisions between great powers. Second, why should oil states make threats more often? We have shown that great powers have little interest in restraint, but this is not necessarily the same as saying that oil states allied with great powers will make threats more frequently. To answer these two questions, we suggest three linking mechanisms whereby alliances, in combination with the enhanced autonomy noted above, can increase the incidence of oil-state aggression.

The first mechanism is deterrence. According to this logic, petrostates ally with great powers out of a desire to gain security benefits. In so doing, they become less vulnerable to

\footnotetext{
${ }^{13}$ By early 1966 economic credits extended from the Soviet Union to Iran totaled 346 million dollars. In 1967,
} a 110 million dollar Soviet-Iranian arms deal was announced, too. 
retaliation from other states. If an oil state takes aggressive action, it can be confident that other states will be less likely to retaliate against it given both the external balancing power of its ally and the enhanced internal balancing capabilities offered by arms sales, joint training, and the like.

The second mechanism is entrapment (Snyder 1984). In this case, an alliance provides an opportunity for a petrostate to deliberately involve its ally in its conflicts. Exploiting the security guarantee made by its great power ally, an oil state may initiate or escalate a crisis hoping to force its ally to aid it or risk major disruption or harm to the client state. This effect lowers the expected cost of war and encourages the use of force in a broader range of cases.

Finally, alliances matter because of enhanced interests. In short, an allied great power will face the same pressures noted in our discussion of the effects of oil, only more so. These effects help explain why oil states with alliances might have more freedom of action to take revisionist measures than non-allied oil states. First, as prospect theory suggests, states highly value that which they have, fearing losses more than they value gains. A secure oil-exporting ally is a major asset, and one whose loss would be keenly felt. In combination with the potential for oil states to exploit divisions between great powers noted above, great powers will tend to exert themselves to maintain friendly relations with oil-state allies more than they will to maintain good relations with less closely-aligned countries, even petrostates. Moreover, the volume of trade and commercial arms ties is likely to be much higher between allies. The inherent value of such trade, as well as 
institutional interests within the great power's government, will promote forgiveness of foreign adventurism by the oil-state ally.

In sum, great powers will face stronger pressure to defend an ally than to stop it from coercing others, and indeed often lack leverage in the latter case since endangering the alliance could harm their own interests. Anticipating inaction from its great power ally and protection from a possible backlash, the petrostate more freely uses military force to coerce other states.

\section{Hypotheses and Results ${ }^{14}$}

We have posited that two aspects of oil wealth pressure great powers to permit petrostates' pursuit of revisionist goals: the economic necessity of stable and affordable oil supplies and the related strategic desire to deny an adversary's access to that oil. These mechanisms rationalize the great power's reluctance and tolerance, which would not exist absent the client's oilabundance. In addition, alliance dynamics further incentivize great power acquiescence through deterrence, entrapment, and enhanced interests effects, generating a moral hazard problem that promotes aggression. Consequently, we expect that petrostates allied with great powers will be more belligerent than non-allied petrostates.

\footnotetext{
14 Data for the replication of results presented in this paper, along with explanatory materials, may be obtained at https://dataverse.harvard.edu/dataset.xhtml?persistentId=doi\%3A10.7910\%2FDVN\%2FDBWPVK
} 
We formalize this expectation and the major theoretical alternative in the following hypotheses:

$\mathrm{H}_{1}$ : Oil states with great power alliances are more likely to initiate revisionist MIDs than oil states without such alliances.

(Incentives to Initiate)

$\mathrm{H}_{2}$ : Oil states with great power alliances will be less likely to initiate revisionist MIDs than oil states without such alliances.

(Alliance Restraint)

In both cases, the null hypothesis is that great power alliances have no measurable relationship with MID initiation.

To investigate these hypotheses, we construct a dataset based on Colgan's 2010 data. By doing so, we can include his revolutionary leadership variables as controls in our own models. Colgan's data consist of MID counts taken from the Correlates of War project for 170 countries between the years 1945 and 2001 along with a suite of control variables. To this we added data on alliances and military capabilities drawn from the Correlates of War project. ${ }^{15}$ We then estimate a random-effects longitudinal Poisson (event-count) model to measure the alliance variables' relationship to the incidence of revisionist MIDs (Revisionist MID). The unit of analysis is the country-year and the total number of observations is 6,945.

\section{Dependent Variable}

The dependent variable in our model is Revisionist MID. Its distribution is weighted heavily toward zero: few countries experience a militarized dispute in a given year. The MIDs have been categorized according to which state had revisionist aims or was seen to be "attacking," not according to which state may have fired the first shot. This matches Colgan's analysis and better

${ }^{15}$ Correlates of War Formal Alliance dataset, version 3.03 and National Material Capabilities dataset, version 4.0. Last accessed January 7, 2015. <http://www.correlatesofwar.org/Datasets.htm > 
reflects our intention: to measure whether states with alliances are more likely to take aggressive action toward other states. Below we show the dependent variable's distribution (Table 1). ${ }^{16}$ The outlier is Iran in 1987 with 23 MIDs, which we drop from the statistical model. Doing so does not affect our primary result. ${ }^{17}$

[Table 1 Here]

\section{Independent Variables}

With three exceptions, we include all of Colgan's independent variables alongside our alliance variables. We omit the Major Power and Percent Muslim variables, which are predominately captured in other variables and make no substantive difference in our results. In addition, we add Military Expenditures and Military Personnel from the Correlates of War National Material Capabilities dataset to replace Colgan's GDP measure, better capturing states' military capacity and leaders’ likely expectations about their ability to win military disputes. ${ }^{18}$

We next include our key variables of interest, which identify states with great power alliances. Alliances as defined by the COW data include mutual defense pacts, neutrality and nonaggression agreements, and ententes that obligate consultation in times of armed crisis or attack. A great power alliance is defined as an alliance of any type with either the United States or the Soviet Union between the years 1945 and 1991, and an alliance of any type with the United

\footnotetext{
16 Given the skewed nature of the distribution, we also fitted a logit model with a dichotomous dependent variable coded for initiation in any given year (not shown). This model accorded with the result presented below.

17 Including or excluding 1987 Iran does affect the result of Model 2 presented below. However, two important points must be observed. First, we believe Model 1 is the best specification available for our theory and present Model 2 only as a suggested robustness check on our results. Second, examination of the empirical cases recorded for Iran in 1987 indicates that many of these MIDs involved countries well outside the region with little potential for actual armed conflict or escalation, including South Korea, Norway, Japan, Liberia, Sweden and others. Empty threats, understood by both sides to be empty, do not challenge our theoretical argument. For these reasons, we are comfortable excluding this outlier observation from both models.

${ }^{18}$ We thank an anonymous reviewer for this suggestion.
} 
States in the years 1991-2001. In total, 2,918 of the total country-years had a great power alliance present (42\% of the total), though only 211 of these alliances involved oil states.

Finally, the Great Power Alliance variable is interacted with the Oil State variable to examine those cases in which alliances and oil wealth coexist. This independent variable is of greatest interest to us, since it represents the relationship between having both oil and a great power alliance on propensity to be involved in a revisionist MID. We also include an interaction term for alliances and radical leadership in order to control for the possibility that some unknown process links the alliances with Colgan's radical leadership factor.

All controls are listed in the table below:

[Table 2 here]

\section{Results and Interpretation}

The model results are displayed below. Model 1 is our base model, while Model 2 presents a robustness check described further below: ${ }^{19}$

[Table 3 here]

Our Model 1 results generally support Hypothesis 1. The interaction between Great Power Alliance and Oil State is significant at the standard 5\% threshold $(\mathrm{p}=0.018)$ and has a positive effect. However, Great Power Alliance has no significant effect on its own or in combination with other variables. This finding offers support for our theory: that oil states will be freer to initiate conflicts due to their leverage in the alliance relationships.

\footnotetext{
${ }^{19}$ Missing data result predominately from missing entries for the Polity $I V$ variable (560 missing observations) and Radical Leader variable (538 missing observations).
} 
Predicted probabilities of involvement in a revisionist MID offer one relatively direct interpretation of the model. These probabilities show that alliances have a notable effect only when oil states are involved, and that this effect favors conflict. For example, the average predicted probability of involvement in one or more revisionist MIDs for any given oil state rises from 0.096 to 0.134 when a great power alliance is present. This indicates a $40 \%$ increase in the likelihood that oil states in the dataset will undertake a revisionist MID in any given year as compared to oil states without alliances. Put another way, we would expect an oil state without an alliance to initiate a revisionist MID about once per decade while those with alliances undertake one approximately every seven or eight years.

For non-oil states, great power alliances have no significant effect. Note that oil states without alliances are generally less likely to initiate revisionist MIDs compared to states in general, which matches Colgan's finding on the matter. However, once they enter a great power alliance there is no statistically significant difference between oil states and other states. In a sense, great power alliances “cancel out” oil states’ propensity to avoid revisionist MIDs.

\section{[Chart 1 Here]}

Last, we must consider the possibility that great power alliances may actually be defensive responses to a state's ongoing conflicts or residence in a “dangerous neighborhood," which would reverse the causal arrow of our argument. Model 1 controls for this possibility by including a country's number of neighbors and consecutive years without a MID as controls. However, we fitted an alternative model (Model 2) that replaced Borders and Peace Years with a more direct threat to states' security: enduring rivalries. ${ }^{20}$ When the count of each state's enduring rivalries is included as a control variable, the results do not substantively change and

\footnotetext{
20 See especially Klein et al. 2006, whose data we used in performing the statistical analysis. Only rivalries classified as "enduring" in all versions of the data were included.
} 
the interaction between great power alliances and oil remains significant at the $10 \%$ level $(\mathrm{p}=$ $0.061)$.

Unsurprisingly since rivalries are actually defined in terms of dyadic MID involvement, the Enduring Rivalry variable is highly significant with a positive effect. Given the possible circularity of using MID involvement to explain revisionist MIDs we tend to favor Model 1. Nonetheless, if alliances were primarily responses to state's ongoing security challenges, we would expect the Great Power Alliance x Oil State interaction result from Model 1 to be spurious and disappear once the underlying cause was introduced as a control. Although the effect is somewhat weakened in Model 2, this is not the case. Moreover, a simple cross tabulation confirms that most states join great power alliances absent any enduring rivalries $(2,295$ of 2,866 alliance observations) and that most states with enduring rivalries forgo great power alliances (720 of 1,291 rivalry observations). The real world is complex; it is possible that some great power alliances are defensive products of states' dangerous environments while most are not.

On the whole, our data provide support for hypothesis one (Incentives to Initiate)but no support for our alternative hypothesis (Alliance Restraint). We now turn to a preliminary case study in order to identify the mechanisms that may underpin our quantitative finding.

Case Study: Iran's Occupation of Abu Musa and the Tunbs Islands in 1971 
This section analyzes how Iran's alliance relationship with the US created a permissive environment for Iran's unilateral decision to occupy Greater and Lesser Tunbs and Abu Musa $^{21}$ in November 1971. The Shah's regime falls far short of being revolutionary in the way he seized power and had run the country. ${ }^{22}$ Methodologically, Iran's case therefore helps avoid the confounding factor by isolating alliance factors from Colgan's "revolutionary leadership" variable.

\section{Background}

$$
\text { [Map } 1 \text { here] }
$$

The Greater and Lesser Tunbs and Abu Musa are three small islands located near the Strait of Hormuz (Map 1). Since Britain took control of the islands in 1903-4, Iran had made repeated yet unsuccessful attempts to negotiate the ownership of the islands with their British counterparts. When PM Wilson announced in 1968 that Britain would no longer honor UK defense commitments east of Suez by 1971, the Shah's territorial claims on these disputed islands resurfaced again. ${ }^{23}$ Although British diplomacy "pushed mightily for a settlement" (Mobley 2003: 644) between the Shah and Ras al-Khaimah and Sharjah - two small British protected sheikhdoms who laid claim to the islands in 1971 - Britain

\footnotetext{
${ }^{21}$ Unlike Tunbs, Iran and Britain, with the consent of Sharjah, entered into an MOU regarding Abu Musa, which defined and regulated Iran and Sharjah's respective areas of interest. The negotiated settlement came only at the last minute, however, which still leaves the question of on what grounds Iran anticipated US tolerance toward its revisionist policy vis-à-vis Abu Musa.

${ }^{22}$ Colgan (2010) codes government as revolutionary based on two criteria - (1) whether the power transition to the current regime was based on either use of arms or occurrence of mass demonstration, and (2) whether the government implemented radical domestic changes. The Shah was installed by foreign powers via Operation Ajax in 1953, automatically disqualifying the Shah's government as revolutionary. Also, political and societal changes introduced under his rule were far from being radical or revolutionary.

${ }^{23}$ The history of the dispute goes back further, and is beyond the scope of this article. For a detailed narrative on the history of these islands, see Mehr(1997).
} 
ultimately failed to resolve the sovereignty issue. In the end, Iran invaded the islands on November 30, 1971, the last day of the UK's treaty obligation to defend them.

Iran's claim over the islands had three dimensions. First, there was a genuine sense of historical injustice that these islands were "unjustly seized" by British imperialists. Retaking them was seen almost as a historic mission by the domestic public, effectively tying the Shah's hands (al-Saud 2003: 84). Second, by overlooking the Strait of Hormuz, these islands carried increased geostrategic and military value (Peterson 2011). The Hormuz forms "the very artery" (Foroughi 1977) whereby Iran's entire oil exports along with significant Gulf crudes pass each day, thereby making the security and safety of the passage a national concern for Iran. Third, thanks to huge oil-revenues and its large population, Iran had by 1971 developed an aspiration to become a regional hegemon. ${ }^{24}$ Against the scheduled British withdrawal from the region and Iran's growing military advantage vis-à-vis neighboring states, the Shah's revisionist stance towards the islands “were all related and reflected the Shah's goal of making Iran the preeminent force in the Persian Gulf."(Bill 1988: 198)

\section{US-Iran Relations in 1971}

Despite the rationales to retake the islands, the Shah had to evaluate the adverse consequences, particularly the strong and unavoidable opposition from the Arab states. From Iran's point of view, the resistance had to be either mitigated or remain isolated.

\footnotetext{
${ }^{24}$ By the late 1960s, the population of Iran was around 26 million, far more than the second largest state in the region, Iraq, which had fewer than 10 million.
} 
Under the context of US emergence as a replacement hegemon, this was decisively helped by two factors-Iranian oil resources and the US-Iran military alliance-that forged Iranian anticipation of US tolerance toward its limited revisionist aims.

Iranian Oil: The global oil market underwent a fundamental transformation in the 1960s. With accelerating demand increases, the market was no longer defined by 'supply surplus', and naturally, Iran's position as an oil producer was empowered vis-à-vis the US via two mechanisms.

First, changes in the oil market increased the importance to the US of denying Soviet access to Iranian oil. Particularly with US spare production capacity held by the Texas Railroad Commission rapidly depleting, the strategic imperative to protect the largest Gulf state from Soviet influence was stronger than ever. To make matters worse, the Soviet threat concomitantly loomed larger, as the Soviet Union expressed more interest in Gulf oil as an additional supply source for domestic industries and its satellite states in Eastern Europe (Ross 1981). Indeed, the Soviet Union was expanding its influence in Egypt, Iraq, and India in the early 1970s, encircling US "friends" in the region (Gause 1985). These developments raised alarms in the US, as a loss of Iran to the Soviets would constitute a "major threat to the security of the entire Middle East," (Randall 2005) and would "...wipe out the benefits which we had received from the Marshall Plan and NATO." (Cohen 2005: 32) 
Second, as the second largest oil exporter, Iran's role in ensuring stable and reasonably priced oil supplies increased during the ongoing transition to a "seller's market" (Yergin 1992) in the late 1960s. ${ }^{25}$ Stability and friendliness of Iranian oil policies was a long-time concern for the US. As early as 1951, it was estimated that disruption in Iran's oil export and refinery capacity "would temporarily undermine economic activity in Western Europe and impose severe economic hardships on Great Britain even in peacetime...", requiring "at least six months...to place marginal plants in operation, to change the composition of refinery output, to alter tanker routings, and to complete the redistribution of crude oil among the other refineries." (Randall 2005: 257-8) Although Iran rarely exercised such power to manipulate political outcomes (including in 1973), the sheer volume of oil reserves and production capacity conferred undeniable power to Iran.

In 1957, President Eisenhower was prepared to "use force" (Gause 1985: 258) in a crisis threatening the West's access to Mideast oil. The US commitment to the safety and friendliness of Iranian oil grew even more with the price increases during the 1960s. Under the growing structural power Iran began to yield, neither US diplomatic leverage nor incentives to risk upsetting access to Iranian oils were easily found.

US-Iran Alliance: It is worth noting that all petrostates were subject to structural changes in the global oil market, but not all benefited from a favorable security

\footnotetext{
${ }^{25}$ It is worth noting that US reliance on Iran and the Middle East itself was relatively low. Its interest came from the broader grand strategy needs, or the severe adverse consequences that US allies in Europe and Asia would face should Iran decide to disrupt its oil exports. The 1973 oil shock is the most illustrative example of oil being used as a weapon that can cause major economic, social, and political discord in and between the US and its allies.
} 
environment the way Iran did. Rather, it was the interaction with the US military alliance that produced a particularly powerful moral hazard problem.

The US-Iran relationship at the time originated from the success of 'Operation Ajax' in 1953, which was further elevated with a mutual defense agreement in 1959. From the mid1960s, however, the security landscape in and around the alliance began to shift, entailing greater military and diplomatic advantages for Iran vis-à-vis other Gulf States.

First, the forthcoming US hegemony was sympathetic or even supportive of the Shah's regional aspirations. This markedly contrasted with the British disdain for Iran as a revisionist power which regarded Iran's territorial claims as a threat to regional stability. ${ }^{26}$ Instead, the Nixon administration regarded Iran as a stable, strong, and modernizing monarchy (Alvandi 2012: 356-360), whose foreign policy orientation was considered largely compatible and whose leader was deemed "our friend" (Alvandi 2012: 365). As Nixon bluntly put it, "I like him (the Shah), I like him, and I like the country." (Conversation among President Nixon, MacArthur, and Haig, 1971)

The warm relationship was further coupled with a broader US strategic desire to increase the strategic role of its allies. As manifested in the Nixon Doctrine in 1969, the US decided to rely on local powers for regional stability and security, which meant that in the context of the Middle East, the US would expect Iran to play a larger military role as a regional power to stabilize the region, secure Western interests, and deter hostile states

${ }^{26}$ Most of the territorial claims also happened to involve the British protected states of Bahrain, Sharjah, and Ras al-Khaimah. 
such as Iraq and the Soviet. ${ }^{27}$ Compared to the unfriendly UK hegemony, US confidence and reliance on Iran created a favorable security environment for the Shah to pursue Iran's long-held revisionist aims in the region. In the new era, there were good grounds for the Shah to believe that the US would not intervene in settling territorial disputes "by force if necessary", (Ettela'at, 1971) as long as the overall stability of the region was not disturbed.

Second, as an ally with growing importance, the US had provided large sums of military aid and allowed Iran to buy some of the most advanced weapon systems since as early as the 1960s. Concern over a Soviet advance, whether realistic or exaggerated, was genuine among US policymakers throughout the Cold War, and the aim of assisting an Iranian military build-up took the form of providing "...a defensive delaying capability against Soviet forces." (Cohen 2005) The US provided substantial military aid, dominating Iran's military development until 1964 (al-Saud 2003: 24), and with its oil-backed arms purchasing power, Iran purchased some of the most sophisticated arms available from the Western world (Pryor 1978: 59, Gause 1985: 264) ${ }^{28}$ under preferential terms of purchase.${ }^{29} \mathrm{As}$ a result of continuing arms purchases, Iran rapidly transformed its mostly incompetent and weak army into "a credible deterrent against any threat in the region", (Jensen 1985: 340) and the unrivalled power within the region with increasing offensive capability.

\footnotetext{
27 The US policy is often termed "Twin Pillars", referring to Iran and Saudi Arabia as US-supported primary guardians of the Gulf. Despite the implied equal responsibility and status in name, Iran was an indisputably larger and mightier country than Saudi Arabia in practice, and Iran was accordingly expected to play a larger military role. See Gause(1985); al-Saud (2003) pp. 66; Shlaim(1995) pp. 61-62.

${ }^{28}$ These arms included hovercraft and tanks from Britain, F-4s from the US, and helicopters and Sea Killer Mk2 ship-to-ship missiles from Italy.

${ }^{29}$ See Gause(1985) pp. 264. "In 1970 and 1971, Washington extended credits totaling \$220m to Iran for the purchase of F-4E Phantom fighter-bombers. Some of these credits came from the Export-Import Bank, which usually refuses to finance military sales."
} 
Third, Iran's reliance on US assistance for domestic stability also gradually weakened after the mid-1960s. The chief reason was the oil price upsurge, which placed huge oil revenues at the Shah's disposal. With the economy developing at an annual growth rate of 10-12 percent accompanied by inflation rate below 2\% (World Bank data) the oil rent contributed to dampening social unrest and garnering political support for the regime.

\section{Summary}

Overall, by the time Iran decided to invade the three islands in 1971, Iran had by far the most powerful military in the region and enjoyed relative stability at the domestic level. The US, on the other hand, reinforced Iranian primacy through military aid and the arms trade, as well as by expressing its intention to rely on Iran for maintaining the regional balance of power.

Iran's invasion of Abu Musa and the Tunbs took place in the absence of a revolutionary history on the part of the aggressor, methodologically allowing us to isolate the effects of Iranian alliance wit the US. Our case study strongly suggests that it was the alliance structure that intensified amoral hazard problem by which Iran's anticipation of US inaction and tolerance fomented a highly permissive atmosphere for the Shah to pursue his revisionist foreign policy. US tolerance was derived from some of the mechanisms described in the theory: oil's strategic and commercial value, concern over an adversary's access to oil, and enhanced interests, all of which interacted with complex regional and temporal settings. 
What of our first characteristic of alliances: deterrence by the great power patron of military retaliation against petro-aggression? In this case, US deterrence was not necessary as the two sheikdoms were much weaker militarily and the Gulf states were far from united, making the Iranian military sufficiently strong to repel military backlashes.

Tellingly, Iran's revisionist impulse remained unobstructed by its security ties with the US, which in fact, grew stronger after 1971. A year after the invasion of Tunbs and Abu Musa, the restriction on Iranian arms purchases was effectively removed, which let the Shah purchase anything he wanted short of nuclear weapons (Shlaim 1995: 63) ${ }^{30}$ From the US point of view, the successful invasion was a manifestation of Iran's reliability as a partner, not a threat to the region's security (Alvandi 2012: 365-6). Iran continued to launch militarized conflicts throughout the 1970s, including the dispatch of its military to fight the communist insurgency in Dhofar, Oman between 1972 and 1979. In Iraq, Iranian units fought in the Iraqi forces supporting the Kurdish resistance, and the Shah showed little hesitancy in escalating tensions with Iraq over the disputed Shatt-al waterway until Saddam Hussein finally gave in by signing the 1975 Algier Agreement.

While a full elaboration is beyond the scope of this paper, Iraq's foreign policy behavior at this time also appears to conform to our theoretical expectation, especially toward neighboring Kuwait. In March 1973, Iraq attacked the Kuwaiti border post of Al-Samitah and claimed the islands of Warba and Bubiyan, as part of efforts to fortify the

\footnotetext{
30 By the mid-1970s Iran accounted for half of American arms sales abroad, and arms sales became the central component in US-Iranian relations. Alvandi (2012) pp. 370 (\$94.9million in 1969, \$682.8m in 1974, \$2.55billion in 1977)
} 
geostrategically significant port and naval base of Umm Qasr (Kelly, 1974). While several factors accounted for the decision to escalate the border dispute with Kuwait, the fact that the Soviet Union-Iraq security ties were strong in 1973 following the conclusion of the Treaty of Friendship and Cooperation in April 1972 created a particularly favorable strategic environment for Iraq. The Soviet Union's military interest in Iraq was based partly on Iraqi oil (Fukuyama, 1980). Indeed, the Soviet Union scaled up military assistance before and after the 1973 border crisis, and provided diplomatic support by giving "moral support" and paying a "friendship" visit by Admiral Gorshkov and a contingent of naval ships (Kelly, 1974).

\section{Conclusion}

Petro-aggression is a simultaneously consequential and understudied phenomenon in international security (Koubi et al 2013). Indeed, petrostates with expansionist or revisionist aspirations still continue to launch MIDs, including Azerbaijan over NagornoKarabahk and Chad in the Central African Republic. And yet, these regimes do not qualify as revolutionary, ${ }^{31}$ and instead, their challenge to alter the status quo may be driven in part by their substantive security relationship with major powers like the US for Azerbaijan or France for Chad.

${ }^{31}$ None of these states are coded as revolutionary according to Colgan (2010) 
How can petro-aggression be reduced? Seeing petro-aggression as a byproduct of the moral hazard problem compels us to shift the focus away from domestic politics to the broader strategic environment. Our analysis suggests that great powers, presumably interested in preventing petro-aggressions committed by their protégé allies and thereby avoiding being entrapped in conflicts unrelated to commitments made for reasons of energy security, may be well-advised to adopt a combination of the following three policies recommendations.

First, great powers should make the conditions for their intervention in petro-states' conflicts explicit and public. The design of the alliance matters here. Good alliance design can lessen moral hazard problems by clearly setting out the conditions under which the great power will militarily aid its oil-state ally. This is not necessarily the case for several US alliances with oil-states, which are often either unwritten (Saudi Arabia) or classified (Kuwait). Some argue that strategic ambiguity can reduce the temptation of protégé allies to test a great power's resolve (Benson 2012). However, as argued above, the presence of oil can undermine the logic of deterrence by strategic ambiguity. In other words, to the extent that oil is perceived as a strategic good, oil-states are more likely to anticipate the great power's support for their military adventures than similar non-oil states would. To address this problem, the US may be well-advised to make public that its commitments to oil-state allies are limited to conflicts of a defensive nature, and even that revisionist aggressions by its protégé ally will be met with punitive measures such as troop withdrawals or retraction of military cooperation. In the context of the ongoing diversification of global oil supplies and growing market resilience against supply shocks 
(Gholz and Press 2010), bargaining leverage increasingly favors the US ability to make these conditions credible to its protégé petrostate allies.

Second, while alliance design allows the great power to clearly state the bounds of its commitment up front, interactions with the ally over time can also be calibrated to limit the moral hazard inherent in such a relationship. A bilateral example might concern arms sales. While great powers already take the broader regional security context into account when making such sales, great powers considering arms sales to enhance the security of a petrostate ally should make this context the first, if not only, priority. Increasing a petrostate ally's ability to take military action, defend itself, or make a military threat has special risks for the great power that should not be lightly run for the sake of a domestic or foreign defense establishment, a temporary boost in bilateral relations, or other minor reasons. Multilaterally, great powers might also consider cooperating over the long term to more generally reduce their level of military commitment to petrostate allies in the Middle East. Shared dangers can create shared interests, and while the pressures to arm and aid petrostates are strong, a recognition of the risks amongst great powers such as the United States, Russia, and China might form the basis for an informal or formal arrangement to limit the degree of military assistance or arms transfers.

Third, great powers can raise the cost of aggression in general. Unlike revolutionary history, which is effectively unalterable, international responses can alter the political stances of petrostate patrons, or more broadly, the costs of aggression. For instance, we suggested that even if a petrostate is run by a revolutionary leadership such as Saddam's Iraq or Chavez's Venezuela, the likelihood of launching MIDs may still be reduced if the 
petrostate sees itself as unable to handle the possible international backlash. In that sense, the events leading up to the Gulf War are revealing. Had the US been more forthcoming in informing Saddam of the US's determined opposition prior to the invasion of Kuwait, it has been argued that Saddam's deep-seated aggressive impulse might nevertheless have been moderated, as direct confrontation against US forces hardly served Saddam's interests (Mearsheimer and Walt 2003). The great power alliance status, by its definition, sends signals about the great power's possible tolerance toward a petrostate's revisionist aims. Accordingly, greater policy efforts would be necessary to dissuade petrostates who are allied with great powers from launching MIDs. At the same time, however, such international efforts would be a much more practical way to prevent aggression than attempting to change a petrostate's revolutionary regime.

Finally, our analysis may be subject to modification as two competing changes occur in the global oil trade and international system. On one hand, US and other developed countries' reliance on oil is declining with the progress made in alternative energy sources, extraction technology for unconventional oils, and the posited decline of the non-Western world's share of global oil production. The current transformation of global oil suggests a reduction, though not total elimination, of great power commitments to petrostates. On the other hand, with the rise of China and its thirst for energy, oil-rich regions now interact more intensely with the potential new patron candidate. China's expansion into oil rich African, Middle Eastern, and Latin American states is still at an early stage, but growing military ties and nascent strategic alignments appear irreversible to many analysts (Leverett and Bader 2005/6, Gao and Wang 2012). Overall, the international security 
environment is being transformed around petrostates, as the traditional patron, the US, debates whether to reduce its current military commitment to oil-rich states, while a rising China makes no secret about its commitment to better access to oil and increased military and political ties with petrostates. 


\section{Bibliography}

Acemoglu, Daron, Mikhail Golosov, Aleh Tsyvinski, and Pierre Yared. 2012. "A Dynamic Theory of Resource Wars”. The Quarterly Journal of Economics, 127(1): 283-331.

Al-Saud, Faisal bin Salman and Inc ebrary. 2003. Iran, Saudi Arabia and the Gulf: Power Politics in Transition 1968-1971. New York: I.B. Tauris.

Alvandi, Roham. 2012. "Nixon, Kissinger, and the Shah: The Origins of Iranian Primacy in the Persian Gulf." Diplomatic History 36 (2): 337-372.

Benson, Brett V. 2012. Constructing International Security: Alliances, Deterrence, and Moral Hazard. New York: Cambridge University Press.

Bill, James A. 1988. The Eagle and the Lion: The Tragedy of American-Iranian Relations. New Haven: Yale University Press.

Byman, D. Kenneth Pollack, and Matthew Waxman. 1998. "Coercing Saddam Hussein: Lessons from the Past." Survival 40 (3): 127-151.

Chan, Steve. 1980. "The Consequences of Expensive Oil on Arms Transfers." Journal of Peace Research 17 (3): 235-246.

Cohen, Michael Joseph. 2005. Strategy and Politics in the Middle East, 1954-1960: Defending the Northern Tier. New York: Frank Cass.

Colaresi, Michael and William Thompson. 2002. "Hot Spots or Hot Hands? Serial Crisis Behavior, Escalating Risks, and Rivalry." The Journal of Politics 64:4, pp. 1175-1198.

Colgan, Jeff. 2010. "Oil and Revolutionary Governments: Fuel for International Conflict." International Organization 64 (4): 661-694. Press.

2013a. Petro-Aggression: When Oil Causes War. Cambridge: Cambridge University 2013b. "Fueling the Fire: Pathways from Oil to War", International Security, 38(2): 147-180.

Conversation among President Nixon, MacArthur, and Haig, Washington DC, April 8, 1971, Foreign Relations of the United States, 1969-1976, E-4, 122. 
De Soysa, Indra, Erik Gartzke, and Tove Grete Lie. 2009. "Blood, Oil, and Strategy: On the Relationship between Petroleum and Interstate Disputes." Norwegian University of Science and Technology, Trondheim, 20 Feb.

Ettela'at editorial, Tehran Home Service, 27 June 1971.

Foroughi, Mahmoud. 1977. "Iran's Policy toward the United States", Symposium on Iran, Washington DC, October, The Institute for International, Political and Economic Studies - Teheran and Stanford Research Center.

Fukuyama, Francis. 1980. “The Soviet Union and Iraq since 1968”, A RAND Note, July.

Gao, Zhixiong, and Ying Wang. 2012. "ZhongguoShiyouGongsiTouziWeineiruila: Moshi, XiaoyiyuFengxian [CNPC's Investment in Venezuela: Model, Benefits, and Risks]." Lading MeizhouYanjiu [Journal of Latin American Studies] 34 (2): 54-60.

Gause, F. Gregory. 1985. "British and American Policies in the Persian Gulf, 1968-1973." Review of International Studies 11 (4): 247-273.

Gholz, Eugene and Daryl Press. 2010. "Protecting 'The Prize': Oil and the U.S. National Interest." Security Studies 19 (3): 453-485.

Glaser, Charles. 2010. Rational Theory of International Politics: The Logic of Competition and Cooperation. Princeton, N.J: Princeton University Press. 38(2): 112-146.

Goertz, Gary \& Paul Diehl. 1993. "Enduring Rivalries: Theoretical Constructs and Empirical Patterns." International Studies Quarterly 37:1, pp. 141-171.

Hamilton, James D. 1983. "Oil and the Macroeconomy since World War II." The Journal of Political Economy 91 (2): 228-248.

Hughes, Llewelyn, and Phillip Lipscy. 2013. "The Politics of Energy." American Review of Political Science 16.

Hughes, Llewelyn, and Austin Long. 2014/15. "Is There an Oil Weapon?: Security Implications of Changes in the Structure of the International Oil Market", International Security 39(3): 152-189.

Kelanic, Rosemary. 2012. "Black Gold and Blackmail: The Politics of International Oil Coercion." Dissertation, the University of Chicago. 
Kelly, Anne M. 1974. "The Soviet Naval Presence during the Iraq-Kuwaiti Border Dispute: March-April 1975", Professor Paper 122. June. Center for Naval Analyses.

Klare, Michael. 2001. Resource Wars: The New Landscape of Global Conflict. 1st ed. New York, NY: Metropolitan Books.

Klein, James, Gary Goertz and Paul Diehl. 2006. "The New Rivalry Dataset: Procedures and Pattern." Journal of Peace Research 43:3, pp. 331-348.

Koubi, Vally, Gabriele Spilker, Tobias Bohmelt, and Thomas Bernauer. 2013. "Do Natural Resources Matter for Interstate and Intrastate Armed Conflict?" Journal of Peace Research, pp1-17

Leverett, Flynt and Jeffrey Bader. 2005/6. "Managing China-US Energy Competition in the Middle East", The Washington Quarterly, 29 (1): 187-201

Licklider, Roy. 1988. "The Power of Oil: The Arab Oil Weapon and the Netherlands, the United Kingdom, Canada, Japan, and the United States." International Studies Quarterly 32 (2): 205-226.

Mangold, Peter. 1978. Superpower Intervention in the Middle East. London: Croom Helm.

Mearsheimer, John J. 2001. The Tragedy of Great Power Politics. New York: Norton.

Mearsheimer, John J. and Stephen M. Walt. 2003. "Can Saddam be Contained? History Says Yes." Foreign Policy Bulletin 14 (1): 219-224.

Mehr, Farhang. 1997. A Colonial Legacy: The Dispute Over the Islands of Abu Musa, and the Greater and Lesser Tunbs. Lanham, Md: University Press of America.

Mobley, Richard A. 2003. "The Tunbs and Abu Musa Islands: Britain's Perspective", Middle East Journal, 57(4): 627-645.

New York Times. 1990. “U.S. gave Iraq Little Reason Not to Mount Kuwait Assault,", by Elaine Sciolino with Michael R. Gordon, http://www.nytimes.com/1990/09/23/world/confrontation-in-the-gulf-usgave-iraq-little-reason-not-to-mount-kuwait-assault.html

Pryor, Leslie M. 1978. "Arms and the Shah." Foreign Policy (31): 56-71.

Randall, Stephen J. 2005. United States Foreign Oil Policy since World War I: For Profits and Security. Montreal: McGill-Queen's University Press.

Ross, Dennis. 1981. "Considering Soviet Threats to the Persian Gulf." International Security $6(2): 159-180$. 
Ross, Michael L. Forthcoming . "What have we learned about the resource curse?", Annual Review of Political Science.

Rovner, Joshua. and Caitlin Talmadge. 2014. "Hegemony, Force Posture, and the Provision of Public Goods: The Once and Future Role of Outside Powers in Securing Persian Gulf Oil", Security Studies 23 (3): 548-581.

Shlaim, Avi. 1995. War and Peace in the Middle East: A Concise History. New York: Penguin Books.

Snyder, Glenn H. 1984. "The security dilemma in alliance politics." World Politics 36(4): 461-495.

Waltz, Kenneth. 1979. Theory of International Politics. New York, NY: Random House.

Yergin, Daniel. 1992. The Prize: The Epic Quest for Oil, Money, \& Power. New York: Free Press.

Yuen, Amy. 2009. "Target concessions in the shadow of intervention." Journal of Conflict Resolution 53(5): 745-773 


\begin{tabular}{c|rrr}
\multicolumn{1}{c|}{$\begin{array}{c}\text { Initiated } \\
\text { MIDS }\end{array}$} & Frequency & Percent & Cumulative \\
\hline 0 & 5923 & 85.28 & 85.28 \\
1 & 793 & 11.42 & 96.70 \\
2 & 171 & 2.46 & 99.16 \\
3 & 34 & 0.49 & 99.65 \\
4 & 12 & 0.17 & 99.83 \\
5 & 4 & 0.06 & 99.88 \\
7 & 3 & 0.04 & 99.93 \\
8 & 1 & 0.01 & 99.94 \\
9 & 2 & 0.03 & 99.97 \\
11 & 1 & 0.01 & 99.99 \\
23 & 1 & 0.01 & 100.00 \\
\hline Total & 6945 & 100.00 &
\end{tabular}

Table 1: DV Distribution

\begin{tabular}{|l|l|}
\hline Variable & $\begin{array}{l}\text { Unit/Description } \\
\text { (per country-year unless noted) }\end{array}$ \\
\hline Great Power Alliance & Dummy variable for alliance \\
\hline Oil State & Dummy variable (oil > 10\% of state GDP) \\
\hline Radical Leader & Dummy variable for radical leadership \\
\hline Alliance $x$ Oil State & Dummy variable for interaction effect \\
\hline Alliance x Radical Leader & Dummy variable for interaction effect \\
\hline Radical Leader $x$ Oil State & Dummy variable for interaction effect \\
\hline Ln Military Personnel & Natural log of total military personnel in millions \\
\hline Ln Military Expenditures & Natural log of total military expenditures in billions of US dollars \\
\hline Ln Population & Natural log of population in thousands \\
\hline Polity IV & Composite Polity IV score ranging from -10 to 10 \\
\hline Borders & Number of contiguous territorial borders \\
\hline Enduring Rivalry & Count variable for rivalries in each year 1945-1989 \\
\hline Cold War & Dummy variable for involvement in an enduring rivalry \\
\hline Region ID & Eight dummy variables for world region \\
\hline Peace Years & 3-knot spline function for number of years since last MID \\
\hline
\end{tabular}

Table 2: Independent Variables 


\begin{tabular}{|c|c|c|}
\hline Great Power Alliance & $\begin{array}{l}-0.078 \\
(0.121)\end{array}$ & $\begin{array}{l}-0.129 \\
(0.124)\end{array}$ \\
\hline Oil State & $\begin{array}{l}-0.693^{* * *} \\
(0.172)\end{array}$ & $\begin{array}{l}-0.690^{* * *} \\
(0.174)\end{array}$ \\
\hline Radical Leader & $\begin{array}{l}0.354^{* *} \\
(0.112)\end{array}$ & $\begin{array}{l}0.398^{*} \\
(0.112)\end{array}$ \\
\hline Alliance x Oil State & $\begin{array}{l}0.469 * \\
(0.198)\end{array}$ & $\begin{array}{l}0.374 \dagger \\
(0.200)\end{array}$ \\
\hline Alliance х Radical Leader & $\begin{array}{l}-0.163 \\
(.165)\end{array}$ & $\begin{array}{l}-0.117 \\
(0.165)\end{array}$ \\
\hline Radical Leader x Oil State & $\begin{array}{l}0.840^{* * *} \\
(0.210)\end{array}$ & $\begin{array}{l}0.896^{* * *} \\
(0.215)\end{array}$ \\
\hline Ln Military Expenditures & $\begin{array}{l}0.085^{* *} \\
(0.031)\end{array}$ & $\begin{array}{l}0.114^{* * *} \\
(0.031)\end{array}$ \\
\hline Ln Military Personnel & $\begin{array}{l}0.129 * \\
(0.060)\end{array}$ & $\begin{array}{l}0.125^{*} \\
(0.063)\end{array}$ \\
\hline Ln Population & $\begin{array}{l}0.030 \\
(0.082)\end{array}$ & $\begin{array}{l}0.085 \\
(0.085)\end{array}$ \\
\hline Polity IV & $\begin{array}{l}-0.008 \\
(0.007)\end{array}$ & $\begin{array}{l}-0.007 \\
(0.008)\end{array}$ \\
\hline Cold War & $\begin{array}{l}0.153 \\
(0.079)\end{array}$ & $\begin{array}{l}0.044 \\
(0.080)\end{array}$ \\
\hline Borders & $\begin{array}{l}0.089^{* * *} \\
(0.021)\end{array}$ & \\
\hline Enduring Rivalry & & $\begin{array}{l}0.292^{* * *} \\
(0.049)\end{array}$ \\
\hline _cons & $\begin{array}{c}-1.881^{*} \\
(0.888)\end{array}$ & $\begin{array}{l}-2.235^{*} \\
(0.956)\end{array}$ \\
\hline$N$ & 6009 & 6009 \\
\hline
\end{tabular}




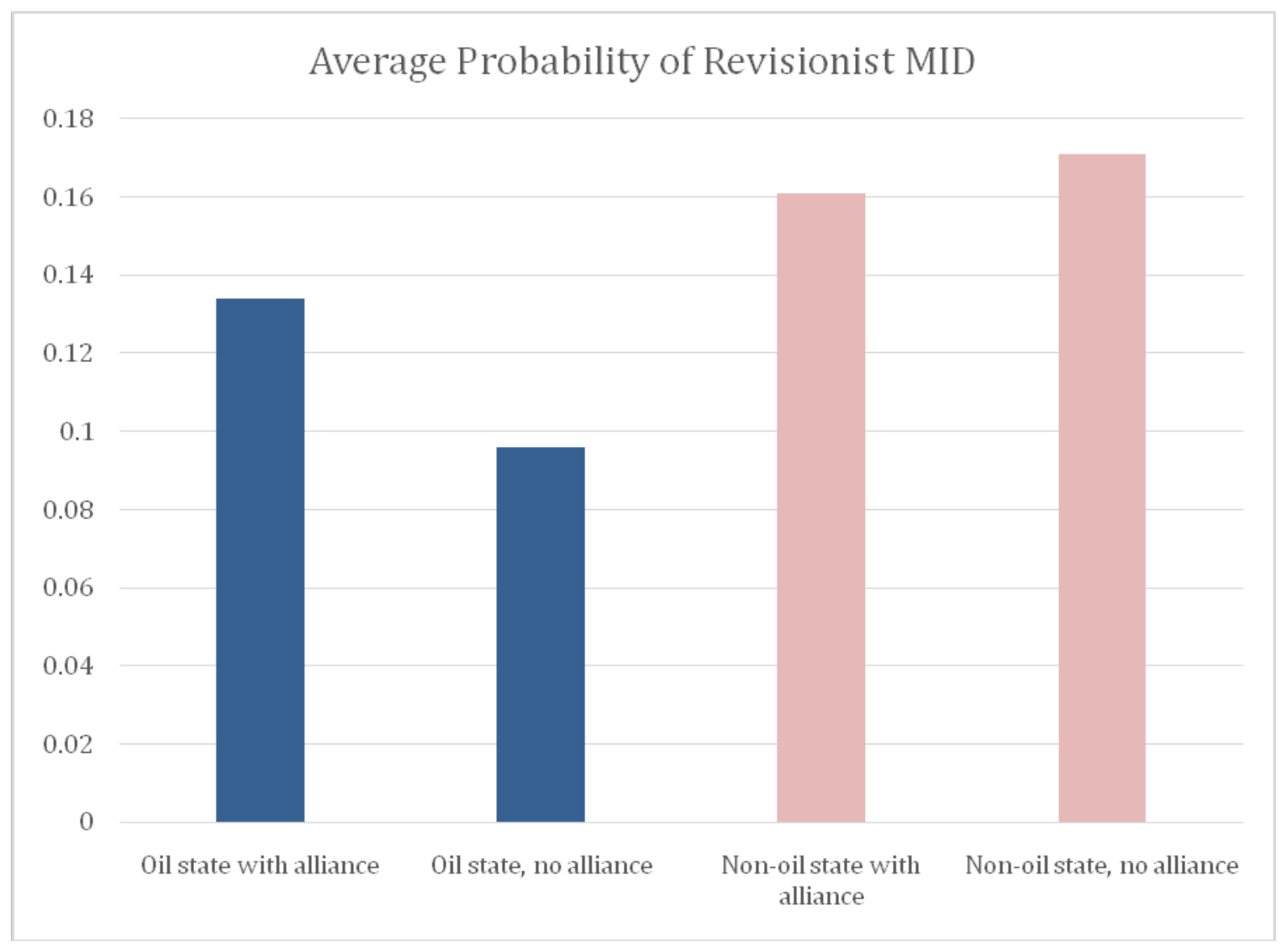

\section{Chart 1: Predicted Probabilities}

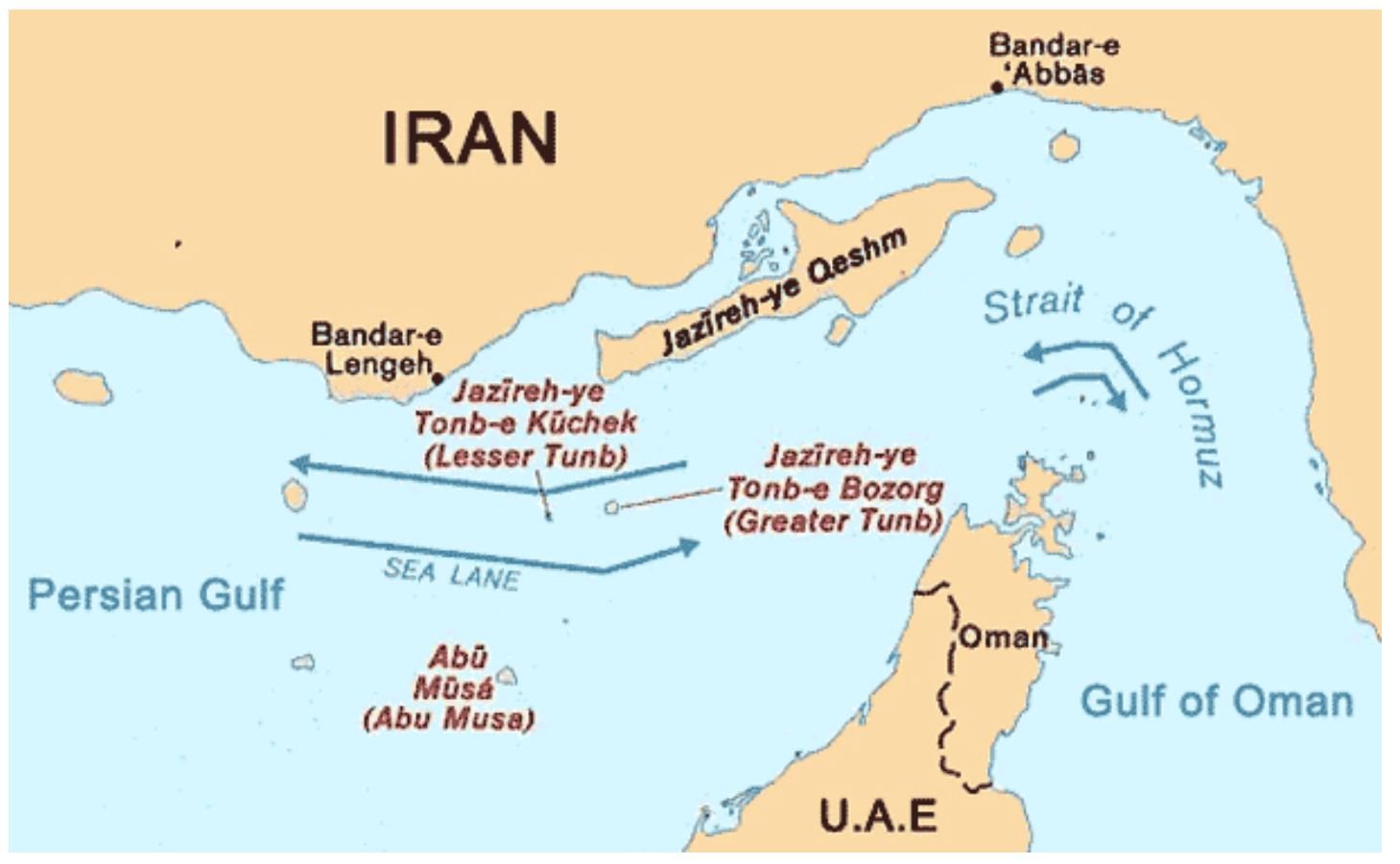

Map 1. Greater and Lesser Tunb and Abu Musa Islands 
